What We Know and What We Do NOT Know About the Willingness to

Provide Self-Financed Old-Age Insurance

Axel Börsch-Supan

17-2002

February 2002 


\title{
What We Know and What We Do NOT Know About the Willingness to Provide Self-Financed Old-Age Insurance
}

\author{
Axel Börsch-Supan \\ MEA, Department of Economics and SFB 504, University of Mannheim, Germany, \\ and National Bureau of Economic Research, Cambridge, Massachusetts
}

\section{Paper Prepared for Kluwer Volume "Good Governments Anticipate Problems"}

\begin{abstract}
As the publicly financed pay-as-you-go pension systems in Europe come under increasing pressure, workers and politicians rediscover private savings for retirement in Europe - the provision of selffinanced rather than state-financed old-age insurance. This paper summarizes our knowledge about the retirement savings motive, and particularly the willingness of individuals to participate in voluntary and/or mandatory private saving schemes for retirement. We also review our knowledge of crowdingout effects, that is, to which extent state-financed old-age insurance substitutes for self-provided old-age insurance, and to which extent retirement saving crowd out other saving.

The state of the art is less than satisfactory. We have little reliable evidence on life-cycle saving patterns and its policy determinants. Moreover, while we have some convincing evidence that there is substitution between public and private old-age insurance, the extent of potential crowding out is still very much disputed. One of the main reasons is lack of suitable data. The paper points to specific strategies that enable our governments to base current and future pension reform decisions on a more solid foundation.
\end{abstract}

\author{
Addresses: \\ MEA, Department of Economics \\ University of Mannheim \\ D-68131 Mannheim, Germany \\ Email: Axel@Boersch-Supan.de
}

Joachim Winter provided helpful comments. I am grateful for financial support by the Deutsche Forschungsgemeinschaft (Sonderforschungsbereich 504) and by the EU (TMR-Project „Savings, Pensions and Portfolio Choice“). 


\title{
What We Know and What We Do NOT Know About the Willingness to Provide Self-Financed Old-Age Insurance
}

\author{
by Axel Börsch-Supan
}

\section{Introduction}

The point of departure for this chapter is the current flurry of pension reforms in Europe, actually, around the world. The reason for these reforms are well known, and it is no surprise that they are particularly debated in Europe: Of the world regions, Europe has the highest proportion of population aged 65 or over (NAS, 2001). Within Europe (and hence in the world), Italy has the highest proportion of people aged 65 or over (18\% in 2000), but also Belgium, Sweden, and Greece score very high (17\% or more). Outside Europe, only Japan has a similar age structure (about $17 \%$ of the population is 65 or over). In Europe, the ratio of persons aged over 65 as a percentage of the working age population 20-64 (the dependency ratio), is expected to increase from about $27 \%$ in 2000 to $39 \%$ in 2025, and to $53 \%$ in 2050 (European Commission, 2000). This increase of the dependency ratio in itself places a heavy financial burden on society.

In addition, Europeans retire much earlier than inhabitants of other developed countries (for instance, in Belgium only a quarter of all males are still in the labour force at age 60, compared to three quarters in Japan, see NAS, 2001), and replacement rates of public pensions are quite generous, requiring a large volume of benefits to be financed by the taxes and contributions of the younger generations. Thus, everything else equal, ageing places a much higher burden on the sustainability of income maintenance systems in Europe than elsewhere in the world.

No wonder then, that governments rediscover the virtues of self-financed old-age insurance in order to relieve the pressure from state-financed retirement income maintenance systems. While this author shares the view that we have no choice but to base a significant part of future retirement income on self-provision (Börsch-Supan, 1999, 2000), designing such a transition is not an easy task. This paper addresses some of the issues involved in such a transition. It focuses on the willingness of individuals to participate in voluntary and/or mandatory saving schemes for retirement. Key to understand this willingness are the various interactions between private saving behavior and state rules. So we begin this paper with a rough estimate how 
much self-financing has to be done in order to stabilize the state-financed pension systems. We then provide a short review of what we know about private saving behavior over the life cycle, both in theory and as evidenced in Europe. We then look at the various interactions: How have the generous public pension systems changed saving behavior? Have they completely replaced the necessity to provide for self-financed old-age insurance? What will happen when the replacement rates of public pensions will decline? Do workers start by themselves to save for retirement - or do we have to provide strong incentives to prevent old-age poverty? Or even stronger: Do we need to make self-financed old-age provision mandatory? If we do so, and workers are actually not willing to save, what is the effect of forcing them? Finally, if workers spend a larger proportion of their income on self-financed old-age provision, what is the effect on consumption and other savings? Will housing prices decline because more savings will be channeled into retirement consumption and less into housing?

As it turns out, we know shamefully little about all these important questions. This begins with the astounding insight that we do not even have reliable evidence to describe how saving behavior looks like over the life cycle, and thus much less on its policy determinants. While we have some - my reading is: convincing - evidence that there is substitution between public and private old-age insurance, the extent of potential crowding out is very much disputed. We have some direct evidence on the workers' willingness to self-insure rather than to rely on public pensions, but the evidence on additional savings is contradictory and scant. We also have some indirect evidence on flight mechanisms like migration into the shadow economy - direct evidence may be too much to ask for in this case. Finally, portfolio choice between pension and other assets, such as housing, is very little understood. We argue that a major reason for this lack of knowledge is lack of suitable data from which to derive such knowledge.

The paper is structured as follows. Section 2 sets the stage by estimating the volume of selffinanced old-age insurance necessary to stabilize a typical European pension system. Section 3 sketches our main theory of savings and the implications that have been drawn by academics and international organizations from this theory on order to make long-run predictions about private saving and its reaction to policy changes. Section 4 collects the available - and contradictory - empirical evidence about actual saving behavior and interprets these findings in the light of self and state-financed old-age provision. Section 5 attempts a synthesis of the contradictions between Section 3 and Section 4. Section 6 is devoted to the issue of substitution and crowding out. Section 7 cites survey evidence whether workers prefer voluntary or mandatory 
self-financed old-age insurance. Finally, Section 8 discusses whether tax incentives work to generate the retirement savings needed.

Section 9 then summarizes what we know and what we do not know, and where it would be quite crucial to have better data in order to anticipate future problems.

\section{How Much Self-Financed Old-Age Insurance is Needed to Stabilize the State-Financed Old-Age Insurance Systems?}

Pension reform is a major policy issue in the countries of Continental Europe. As pointed out in the introduction, they face a common problem: their populations are aging, and this especially quickly from the year 2010 on. The dependency ratios - the demographic parameter of most importance for the old-age-pension systems - will about double, particularly so in Italy and Germany, thereby also about doubling the financial burden of the PAYG pension systems. Since solutions within the PAYG systems are limited in light of this doubling of the burden, almost all pension reform attempts in Europe attempt to make use of self-financed old-age provision. How much saving for old age is necessary to stabilize the PAYG fiscal burden? ${ }^{1}$

We use Germany as an example for a numerical calculation of the volume of pre-funding necessary to stabilize the PAYG contribution rate. Of course, this depends on the policy scenario and a host of other assumptions. We carry out a partial equilibrium analysis and build on the following "natural" policy scenario which we dub the "freezing model" (Birg and BörschSupan, 1999). First within the PAYG system, the effective retirement age will be increased by 3 years and the contribution rate frozen. Second, a pre-funded second pillar finances the emerging aging burden. Concretely, at the end of year 2001, it is announced that the contribution rate will be frozen from year 2008 on at the then current level. Because population aging increases the dependency ratio, this implies a reduction in the replacement rate - a "pension gap" will emerge. We assume that this pension gap will completely be filled by pre-funding

\footnotetext{
${ }^{1}$ Parametric reform steps within the PAYG system, in particularly an increase in the retirement age, can go a long way in stabilising future contribution rates. Unlike to the UK, however, they cannot absorb all the burden in the countries most affected by population ageing. Germany, for example, would need a shift of the average retirement age by 9.5 years in order to fully compensate the increase in the dependency ratio, see Börsch-Supan (2000).
} 
such that the sum of future reduced PAYG pension benefits and new funded pensions will remain equal to the current PAYG pension benefits. ${ }^{2}$

This bookkeeping exercise implies that in response to the increasing dependency ratio, the benefits provided by the frozen PAYG system will shrink to two-thirds of what they are now. Hence, new funded pensions eventually have to provide for about one third of current PAYG benefits. Adding the existing other sources of retirement income, the balance between PAYG and other sources will create a mix in Germany similar to what it is now in the Netherlands and Switzerland. In countries that age less than Germany (e.g. France), the funded share will be lower, while in countries that age more (e.g. Italy), the funded share will be higher if such a freezing policy is applied.

How much new saving is needed in order to provide a third of current pension income? This mainly depends on the instruments used and their rates of return. We design an instrument similar to a group life insurance which covers all three biometric risks (longevity, disability and survivorship) and is paid out on retirement as an annuity. For the sake of simplicity our computations are based on a standardized life course, in which gainful employment begins at age twenty and ends at age 60 (in 2000), the latter gradually increasing to age 63 (in the year 2035). We apply the upper variant of the life expectancy projections used by the most recent government computations. Hence, this insurance covers the individual risk of longevity as well as this projected aggregate increase of longevity. Early disability occurs between age 45 and 60 with an increasing probably averaging 15 percent, the current frequency. Survivor benefits are paid in accordance to the average current probabilities which is likely to be an overestimate because an increasing share of women will have their own pensions. ${ }^{3}$

The pension or insurance company is investing the accumulated capital in the market using a broad portfolio of stocks, bonds, direct placement and real estate. We assume that this portfolio generates the average gross rate of return that prevailed between 1980 and 1995 in the industry. This was $6.5 \%$ in real terms - however, we will also vary this rate in our projections. We subtract administrative costs of $6 \%$ of contributions, the average for group insurance policies. ${ }^{4}$ Here enters the significance of the group policy: past experience has shown that individ-

\footnotetext{
${ }^{2}$ Hence, we only look at the $85 \%$ of retirement income that is currently provided for by the first pillar, see Table 2.1. Details of this and related transition models can be found in Birg and Börsch-Supan (1999).

3 In this case, Germany has a partial offset rule which reduces total claims.

4 Administrating individual policies is more expensive. This is why we choose group policies that can be bun-
} 
ual accounts tend to have higher administrative costs. Group policies and a universal spread of pre-funding "enforced" by the notional account mechanism also minimizes the costs of adverse selection in the annuity market. We do not propose additional incentives or mandatory contributions but a consistent taxation of all retirement benefits together with tax deductibility of all pension contributions.

The resulting net rate of return to the customer is $4.5 \%$ in real terms. One may find this overly optimistic, but we think that the experience between 1980 and 1995 is a fairly good indicator of the future - it includes the "golden years" of the mid1990s as well as the Asian and other financial crises. Nevertheless, we also present simulations with a slightly higher (5.5\%) and a substantially lower real rate of return $(3.0 \%)$. We assume that this rate will decline in the wake of population aging to $4.2 \%$ in 2035 , and then remain constant. This estimate is based on a growth model taken from Börsch-Supan, Heiss und Winter (2001) that simulates the effect of population aging and the feedback of a partially funded pension system on capital intensity and the rate of return.

Figure 1 shows the path of savings and PAYG contributions under the proposed mixed and under the current pure PAYG system for a representative worker. For each birth cohort, it compares the total contributions in the transition scenario - the frozen contributions to the remaining PAYG system (the lower part of the bars, denoted by 1) plus the savings invested in the group account (upper part of the bars, denoted by 2) - with the contributions in a continued PAYG system (3, solid line). The transition smoothens the increase of the total contribution rate relative to the PAYG system, and prevents the total contribution rate from reaching the peak burden of the PAYG system after the year 2035 without changing pension benefits. For cohorts born after about 1970, the transition results in substantially lower total contributions than under the PAYG system. 


\section{Figure 1: PAYG Contributions and Savings Implied by Pension Reform (DM/month at the average wage)}

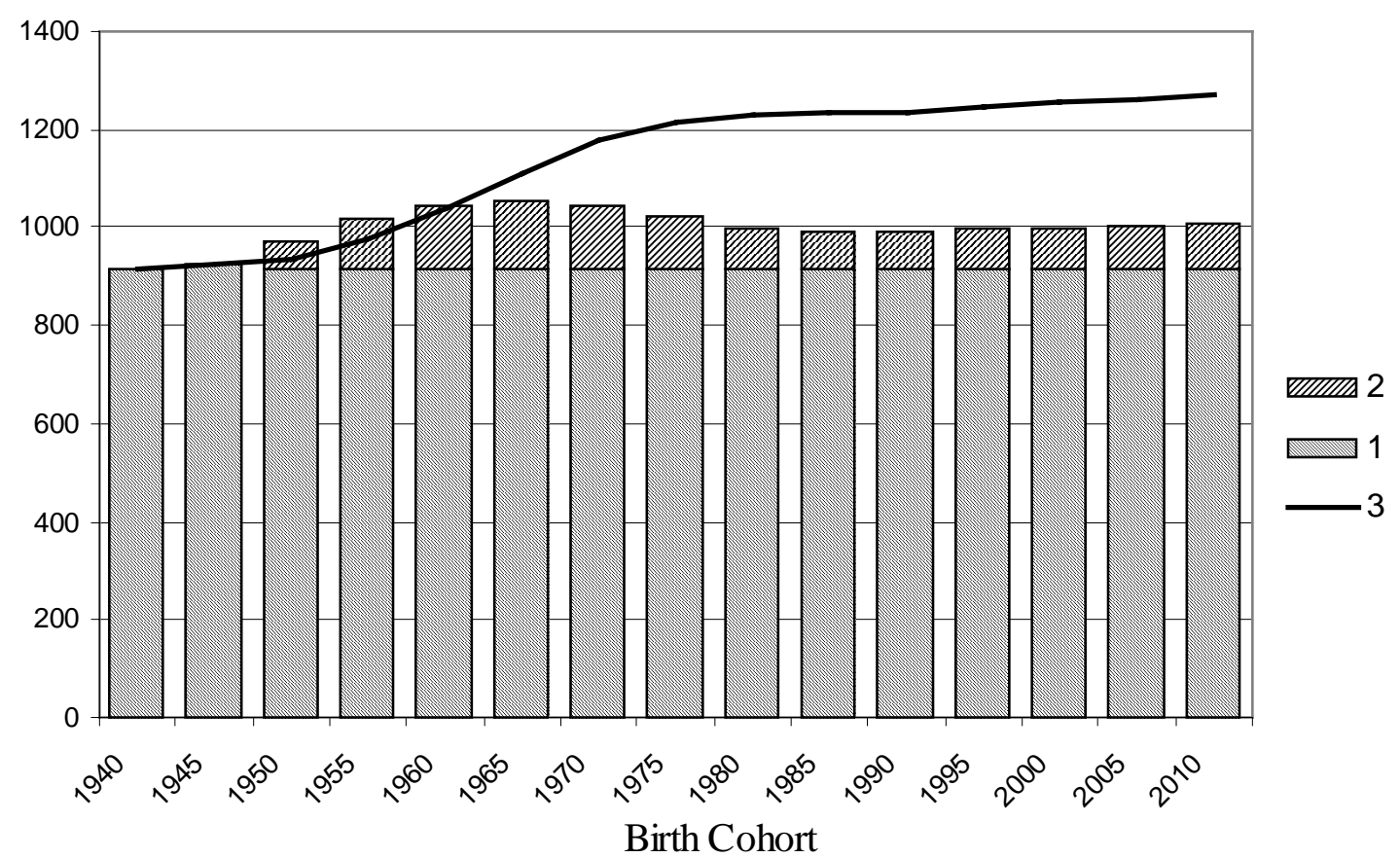

Note: 1000 DM are approximately 500 US-\$ at PPP. The Figure shows PAYG (1) and savings (2) contributions to the mixed system and the PAYG contribution to the old pure PAYG system (3). Replacement rate fixed at the level of 1997. Real rate of return is 4.5\%. Source: Birg and Börsch-Supan (1999).

Note the cohort dependency of savings in Figure 1. Unlike to current government proposals or the Swedish model, the freezing model implies a higher savings rate for the cohorts born around 1965 than earlier or later cohorts. This is most clearly shown in Figure 2. The earlier cohorts need to fill a smaller gap, while the later cohorts have longer time to exploit the force of compound interest. The implied saving rate (i.e., contributions to new pension accounts, expressed as a percentage of gross wages to be compatible to the PAYG contribution rates) is highest for the 1965 cohort and reaches about 3.2\%.

These simulations are sensitive with respect to the assumed rate of return. Figure 2 shows the variation. If rates of return are lower, saving rates need to make up and increase. The peak rate will reach $4.7 \%$ at a $3 \%$ real rate of return, but is only $2.5 \%$ at a $5.5 \%$ rate of return. 
Figure 2: Saving Necessary to Fill Pension Gap (\% of gross income, by rate of return)

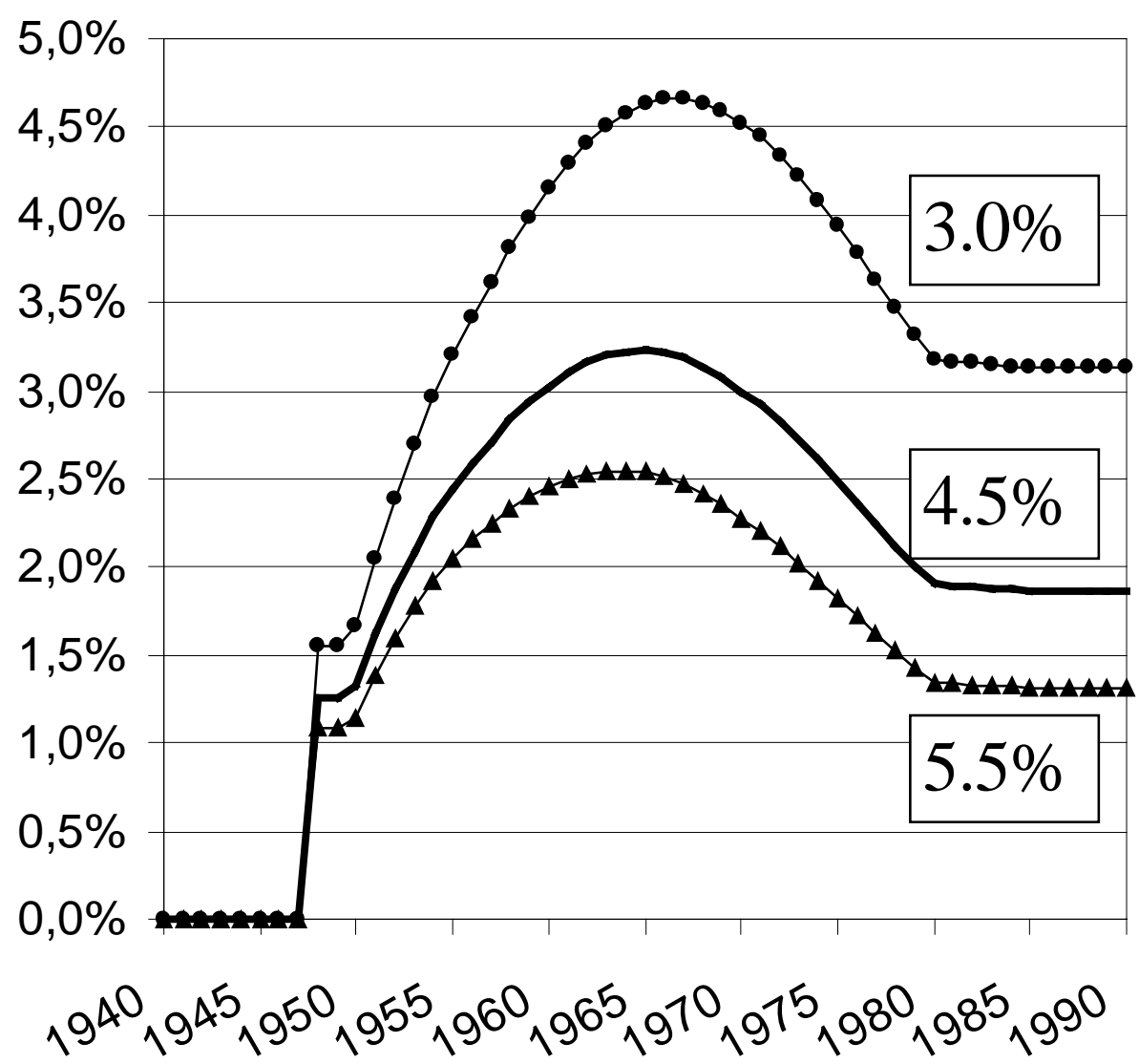

\section{Birth Cohort}

Source: Birg and Börsch-Supan (1999).

The upshot of this simulation is that the private saving rate has to increase by 1.8 percentage points in the long run if the creation of a pre-funded second pillar are the main policy response to population aging (in addition to an increase in the retirement age by 3 years). If one believes in lower future rates of return, say, $3 \%$ rather than the $4.5 \%$ assumed, the private saving rate has to increase by slightly more than 3.2 percentage points. Applied to the 1965 cohort, the saving rate has to increase from some $12.1 \%$ (1998) to $13.9 \%$ or $15.3 \%$, depending on the rate of return.

Extrapolating this simulation to France and most other European countries will generate a smaller gap to be filled than in Germany because Germany is projected to experience one of the highest increases in the dependency ratio in Europe. It will, however, be surpassed by Italy. In this country, households will have to save more than the Germans in order to fill the corresponding pension gap. 
We conclude from this stage-setting section that the volume of saving necessary to fill the pension gap which emerges from a population-aging stable PAYG system is not trivial but well in the realm of the historical variation in German household saving rates. Our estimates are of course subject to parameter criticism. The "freezing model" is in our eyes a "natural" transition model but the reader might like other policy scenarios better. More importantly, however, is the fact that our simple bookkeeping exercise ignores all potential feedback mechanisms. It is not based on a behavioral model of saving.

\section{The Life-Cycle Hypothesis and its Implications for Savings}

Will the workers actually save as much as postulated in the bookkeeping model of the preceding section? Will they do it voluntarily? In order to answer, we need to understand the saving behavior of workers. In the next three sections, we show that we have such a model. However, it is too simple yet to describe the actual saving patterns observed in Europe. Extensions to make it more realistic, however, require better data which we are lacking in Europe.

The main work horse of studying savings from a theoretical point of view is based on Franco Modigliani's seminal work (Modigliani and Brumberg, 1954). The life-cycle hypothesis supposes that households look forward in order to smooth consumption. Hence, households save when income is high and dissave when income is low. A household just as impatient as the average household will smooth consumption to be constant, and its level is determined only by the total income over the life cycle (the permanent income), not its fluctuations. In fact, saving reflects such fluctuations (positive transitory income), while dissaving reflects transitory income losses.

This theory has strong predictions. First, during a stylized life cycle, in which individuals earn wage income until retirement and then receive a much lower retirement income (in form of an annuity), individuals will save until retirement and then dissave. Hence, life-cycle saving profiles should be first positive, then drop to negative values after retirement. Second, as long as retirement income is lower than earnings, asset profiles over the life-cycle saving profiles should be strongly hump-shaped: assets increase until retirement and then decrease during the dissaving period after retirement. Third, in a life course with reasonably steady earnings and substantially lower pension income, retirement saving is by far the most important motive for 
saving. This is simply due to the large volume of income maintenance necessary after retirement.

The life-cycle theory of saving has also a strong prediction for our crowding-out questions posed in the introduction and to which we will return in Section 6. Substitution between stateprovided old-age insurance (a pension annuity) and self-provided retirement income (also received as an annuity) should be exactly one-to-one. Each Euro of benefits provided by a state pension should crowd out exactly one Euro in self-financed insurance benefits.

There may be other reasons to save than for retirement, e.g., to smooth over short-run earnings fluctuations, to finance large indivisible consumption goods (homes, cars), to buffer against uncertainty, and/or to leave bequests. Modigliani's theory can be extended to accommodate these additional saving motives. We can draw a fifth prediction, however, and again it is a strong one: these other saving motives should be unaffected by any change in the ratio between self- and state-provided retirement income - as long as all else (e.g., total disposable income) remains unaffected. There may be second-order feedback effects (e.g., pension policy changes affect risk and uncertainty) but they should be small.

A sixth prediction concerns population aging and it is no less crisp than the other ones. Future saving rates will decline in response to population aging because elderly households who dissave become a larger proportion of the population.

Because Modigliani's life-cycle theory of savings is the only workable theory we have so far, most policy analyses which require a behavioral model of saving use this theory more or less implicitly. Examples are the earlier analyses on the effect of population aging on saving conducted by the IMF and the OECD (Heller, 1989; Auerbach and Kotlikoff, 1987; Auerbach et al., 1989). They use the hump-shaped life-cycle saving patterns and it comes to no surprise that they conclude that future saving rates will strongly decline in response to population aging. Policy makers took these predictions as a strong warning for capital shortages in the 20s and 30 s of this century. Some quoted these predictions to advocate stronger tax subsidies to saving in order to foster the willingness to save, especially through tax-preferred retirement saving vehicles such as individual retirement accounts (so-called "IRAs") and employer-sponsored retirement saving plans (so-called "401(k) plans") in the United States. 


\section{Evidence on Life-Cycle Savings Behavior}

Are these strong predictions correct? This is not only an academic question but has strong policy implications, as we made clear at the end of the preceding section. Will people automatically and voluntarily fill any pension gap created by the retrenchement of public pay-asyou-go pension systems with self-provided old-age insurance (prediction 4)? Will other savings, and therefore corresponding prices and returns, e.g., in the housing market, be unaffected by a fundamental change in pension policy (prediction 5)? Will we need to take expensive measures to prevent future capital shortages (prediction 6)?

Here, we quickly reach the limits of our current knowledge. We have little direct evidence, at least for Continental Europe, because pension systems have stayed fairly unaltered during the last decades. Our line of argument will therefore be: if predictions 1 through 3 about life-cycle saving behavior hold, we might be in a good position to believe also the other three more policy-relevant predictions 4 through 6 . If not, we obviously need to be careful.

It is not straightforward to measure life-cycle savings. First, saving is a complicated concept that has to be measured carefully - as a change in assets, a difference between income and consumption, taking care of inflation as well as potential unrealized capital gains. Second, to understand how saving changes over the life-cycle, one needs to observe households as they age - a single observation in time will not provide that information. Comparing individuals of different ages is not sufficient since these individuals have been born at different times and experienced different earnings and policy histories (Brugiavini and Weber, 2001).

We do not have such data. Hence, we must resort to a mixture of genuine and pseudo-panel data in order to derive a pure life-cycle savings profile. Figure 3 below presents saving rates in Germany, Italy, and the Netherlands. These were derived from reasonable (although by no means perfectly) comparable saving definitions which makes the following results preliminary (Börsch-Supan, 2001a). The figures show the fitted values by age in each observed year together with the upper and the lower point of a 95\% confidence interval. They therefore offer a visual impression of the stability and precision of these age profiles - stability in terms of changes from year to year, and precision in terms of estimated standard deviations. 


\section{Figure 3: Cohort-corrected saving rates by age (medians)}

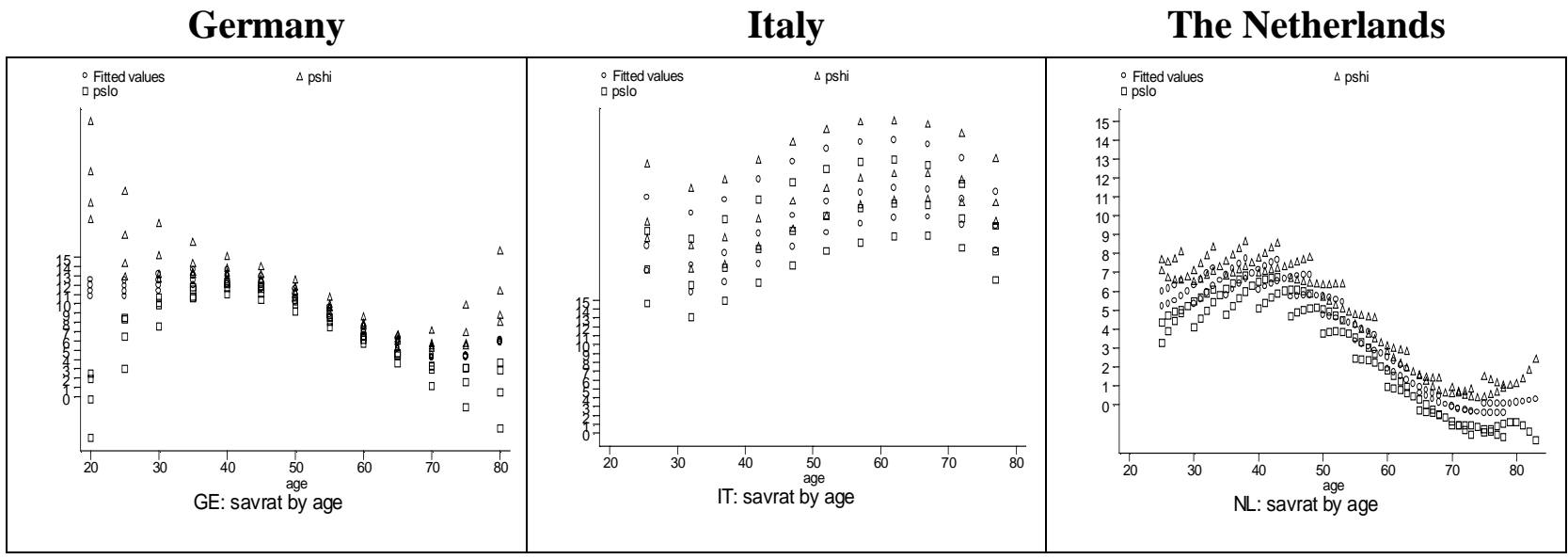

Sources: Germany: Börsch-Supan, Reil-Held, Rodepeter, Schnabel and Winter (2001); Italy: Brugiavini and Padula (2001); Netherlands: Alessie and Kapteyn (2001).

Figure 3 gives a good impression of the diversity of age-saving profiles. First, levels are very different: Italian households have a high saving rate that exceeds the age-specific saving rates of Dutch households at all ages, with German households in between. Second, Italian households have experienced quite different saving rates over time (and possibly cohort) while the savings behavior of Dutch and German households was much more stable. Third, the saving rates of Dutch and Italian households can be fairly precisely measured in a statistical sense. This is also true for German households who are in the middle age groups while sampling errors are large for young and elderly households. Fourth and finally, the life-cycle patterns are rather different: In Italy, a decline in saving rates comes late (after age 60). In Germany, households save less after about age 40 but savings rates appear to slightly (not significantly) increase at old age again. The median elderly household in Germany and Italy does not dissave - in Germany, the saving rate stabilizes at around $4 \%$ and in Italy it remains even higher also in old age. This is quite different in the Netherlands where the median saving rate is about zero for elderly households and slightly negative for the oldest old.

The German and Italian saving patterns look quite different from what the life-cycle hypothesis would predict. Even the Dutch households dissave only very little. Obviously, we cannot use the textbook life-cycle theory naively in a prediction model. This puts a big question mark on the predictions about future capital shortages based on the textbook life-cycle model presented in the previous section. In order to use the life-cycle model, we need to extend it in a way that it will predict the patterns observed in Figure 3. 
Using the actual life-cycle profiles of Figure 3, we do not predict a strong decline in saving rates, see Figure 4. Actually, we predict an increase for a country with demographics like Japan, a slight decline in a country with demographics like the U.S., and we do not really know for countries with demographics like Germany and Italy. The methodology ("shift-share analysis") is simple, see Börsch-Supan (1996): We apply the age and cohort specific saving rates of Figure 3 to projections of population size by age group and of income growth. It is noteworthy that for the purpose of projecting future savings, the high saving rates among households aged 45-64 are significant because the baby boom generation will enter these ages soon, and because income is highest during those ages. The decline after age 65, which is stronger in the cohort-corrected data than in the raw data, is an interesting puzzle in itself (e.g., see Banks, Blundell and Tanner, 2000; Börsch-Supan, 2001b), however, for a projection of total saving it turns out to be less significant because the population weights decrease with age due to mortality and because retirement income is lower than income at age 45-64.

In addition to Germany, we will do this exercise also for Japan and the United States. This is helpful because the underlying age-specific saving rates and speed and extent of population aging are different across countries.

In the United States, population aging during the next 15 years shifts more weight to the high saving ages 45-64. After 2010, the numerous baby boom generation enters the low saving ages $65+$. Hence, as visible in Figure 4, American saving rates increase by 0.5 percentage points from 1990 to 2010, then fall almost to the 1990 level during the following 10 years. In Japan, saving rates increase almost monotonously with age, such that the effect of population aging is similarly monotonous. Population aging puts fewer households in the low saving age categories and more households in the high saving age categories, resulting in higher saving on an aggregate level. Japanese saving rates are projected to increase from 14.3 percent to 15.8 percent during the period considered.

In Germany, the overall effect is ambiguous. Population aging reduces the relative proportion of households below age 37, but it also increases the number of households in the „saving trough" after retirement. The increase in saving rates after age 75 is of smaller relevance because the number of households of very old age is relatively small even after taking account of the projected decline in mortality. As a result, the aggregate household saving rate in Germany - and, since the demographic changes are roughly alike, probably in all of Continental Europe - is almost unaffected by the population aging process through 2020. 


\section{FIGURE 4: Age-Composition Effect in OECD Saving Rates}

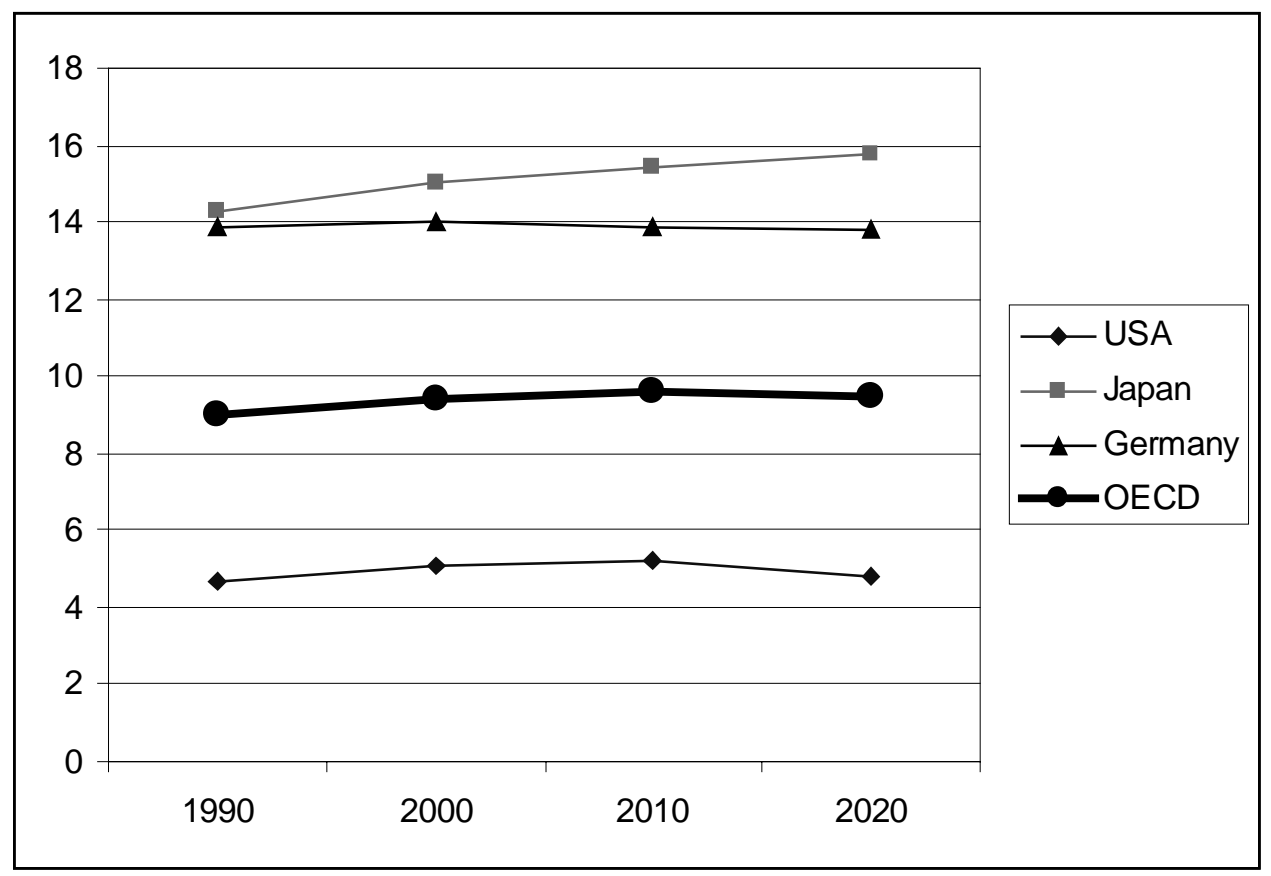

Source: Börsch-Supan (1996)

The results in Figure 4 are in sharp contrast to the projections by Heller (1989), Auerbach and Kotlikoff (1987), and Auerbach et al. (1989) which rest on the theoretical life-cycle profile of saving rates presented in Section 2. Using the actual saving rates depicted in Figure 3, we cannot find an indication for serious capital shortages. Our results rest on the combination of high saving rates and high incomes of the baby boom generation in the year 2010. In 1990, the leading edge of the U.S. baby boom generation was age 44, while the youngest baby boomers were 27 years old. In 2010, the baby boomers are between age 47 and 64, exactly in their peak saving and peak income ages.

\section{What do we know about Future Savings Rates?}

Sections 3 and 4 leaves us puzzling: what is now true as a prediction of future savings? Strong decline with potential need for policy intervention - or essentially unchanged such that one does not even have to contemplate policy action?

The honest answer is that we do not know. The popular projections in Section 3 are based on a model that predicts a much simpler saving behavior than observed in the data. One feels uncomfortable. However, the projections of aggregate saving on the basis of a current description 
of behavior, as done in Section 4, are subject to what is called the "Lucas-critique": How do we know that current behavior will remain stable? Why shouldn't changes in public policy feed back and change saving behavior? This critique makes us feel equally uncomfortable about the predictions of Section 4. Specifically, pension provisions and transfer habits may well be adapted in the wake of population aging when pension systems are adapted to remain financially sustainable. Hence, we realize how central the question is, how self-provided old-age insurance (i.e., retirement saving) will react to changes in state-provided pension income.

We come back to the insight that we need to extend the life-cycle model of Section 3 in a way that enables it to predict the saving patterns observed in Figure 3. The simple textbook model is obviously misspecified. Only the knowledge of the correct model, however, enables us to escape the Lucas-critique. Crucial for the construction of the correct model is longitudinal data, covering several countries with comparable data definitions. Why longitudinal? Because saving is a choice over time, shifting resources from fatter to leaner years. Cross-sectional data will not uncover how people do this shifting over time. Why cross-national? Because in a single country, policy changes rarely, especially pension policy. Cross-national variation is then the only way to include policy variation. And without variation no influence can be measured, no behavior identified, therefore no new model constructed.

The following may exemplify how we would use such data, using the preliminary saving profiles from Figure 3 with all their measurement problems as a departure to predict what might happen in the future.

Consider the pension systems in those three countries as a working explanation for the strong differences between Germany and Italy on the one, and the Netherlands on the other hand. Germany and Italy have pay-as-you-go financed public pensions with very high replacement rates. They generate net retirement incomes that are approximately $70 \%$ of pre-retirement net earnings in Germany and may even exceed $100 \%$ in Italy. ${ }^{5}$ In addition, the public pension systems in Germany and Italy provide generous survivor benefits that constitute a substantial proportion of total unfunded pension wealth, and disability benefits at similar and often even higher replacement levels than old-age pensions. As a result, public pensions are by far the largest pillar of retirement income in these countries and constitute more than $80 \%$ of the income of households headed by persons aged 65 and older, while funded retirement income,

\footnotetext{
${ }^{5}$ See Gruber and Wise (1999) for a comparable description of the Dutch, German and Italian pension systems.
} 
such as asset income from private saving or firm pensions in which the employer saves on behalf of the worker, plays a much smaller role. This is quite different from the Netherlands which only provides a flat base pension on a pay-as-you-go basis with a replacement rate that is very low for households above median income. All other retirement income is withdrawals from mandatory occupational and individual pension accounts.

Hence, a crucial difference between Germany and Italy on the one hand, and the Netherlands on the other hand, is that saving for old age is unlikely to be the main savings motive in Germany and Italy, while it is necessary for Dutch households. The famous hump shape of savings predicted by the life-cycle hypothesis therefore applies better to Dutch households, while (physical) savings are relatively flat in Germany and Italy - in turn, "notional" social security wealth increases and decreases faster in Germany and Italy than in the Netherlands, see the individual country studies in Börsch-Supan (2001a).

Figure 5 tries to make the point clearer by extracting the average profile from Figure 3 (using regression analysis) and indexing the saving rates to $100 \%$ at age 40 . The saving rates in old age very well reflect the replacement rates from pay-as-you-financed public old-age insurance: about $45 \%$ in the Netherlands, $60 \%$ in Germany and $80-120 \%$ in Italy.

\section{Figure 5: Life-cycle saving patterns}

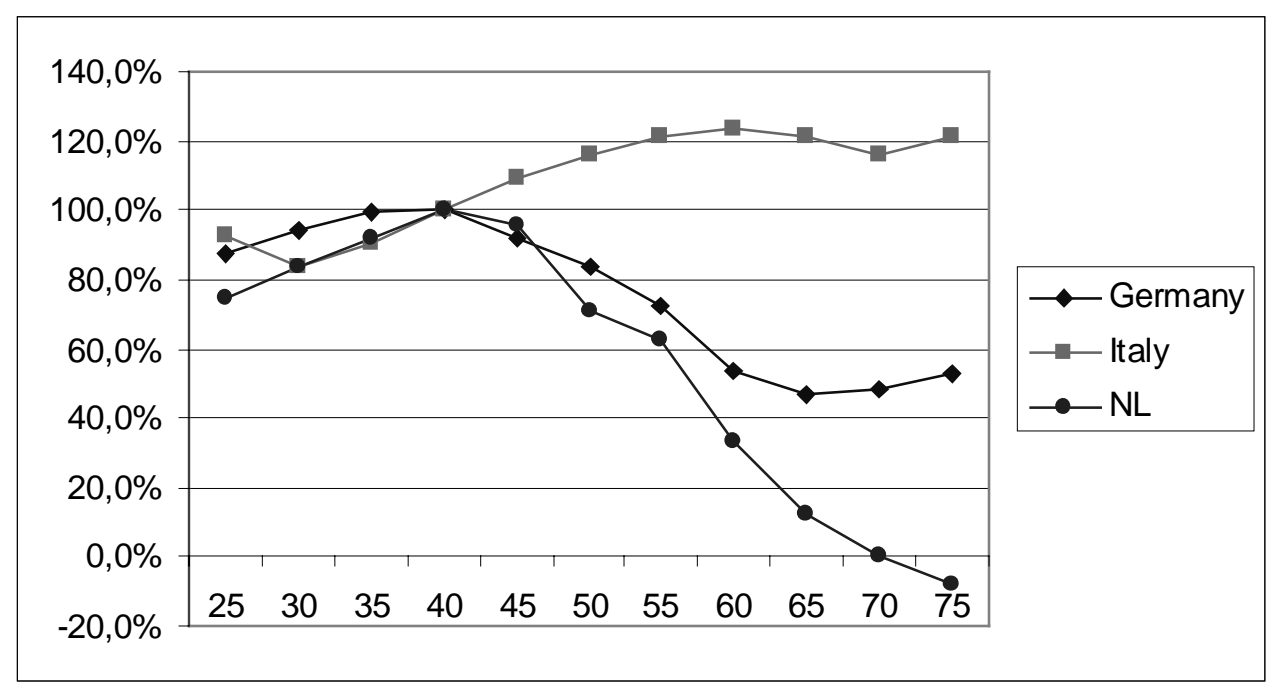

Source: Börsch-Supan and Winter (2001)

If this explanation of the observed cross national saving differences were correct, it has important implications for the future. If indeed most of the saving patterns currently observed in Germany and Italy are caused by generous retirement benefits from their pay-as-you-go pen- 
sion systems, we should expect distinct changes in saving patterns when the pension reforms in these countries will be put in place. The introduction of multi-pillar systems with a substantial portion of funded retirement income will revive the retirement motive for saving. In fact, these reformed systems will look very similar to the current Dutch system. Hence, it is likely that saving rates among the young will increase (to accumulate retirement savings), and saving rates among the elderly will decline sharply (because they will dissolve their retirement savings).

Using the same logic, we should add pay-as-you-go contributions to the savings visible in Figure 5 (as additions to pension wealth), and subtract pension receipts (as withdrawals from pension wealth) in order to do justice to Modigliani's life-cycle theory, as has been done by Jappelli and Modigliani (1998). This would rescue the predictions 1 through 3 in Section 3 but it does not help us lot in explaining what will happen in the future. Why have Dutch households a lower saving rate although we need to add less pay-as-you-go contributions to other Dutch savings? Why do Germany and Italy have such high saving rates although the pension system takes care of their retirement savings? In order to answer these questions, we need to understand the entire variety of saving motives, not only retirement saving. In order to do this, we need to observe how people over their life-courses adapt their savings to changed circumstances. We do not have such panel data in Europe. Hence, we are left with applying predictive models using explicitly or implicitly Modigliani's life-cycle theory although we do know that it cannot answer all our questions on saving behavior.

\section{Substitution and Crowding Out}

Adding pay-as-you-go contributions to other savings in Figure 5 amounts to the assumption that there is no feedback effect of retirement saving to other saving, and that substitution between contributions and saving for self-provided old-age insurance is one to one - as postulated in the life-cycle hypothesis.

It is not clear, however, whether this assumption holds. Going back to Section 2, not all of the additional saving depicted in Figure 2 will be new saving since some other saving will be "crowded out" by the new saving for self-financed retirement income. For example, people may buy smaller homes (and thus save for a smaller down payment) when they have to pay more for their retirement. 
One has to distinguish carefully between two kinds of substitution: (1) substitution between bequethable wealth and wealth that is annuitized for retirement, and (2) substitution within "retirement wealth". 6 Both substitution mechanisms are important in the pension reform discussion. In fact, while all forms of private saving (whether annuitized or not) constitute private wealth accumulation, and are usually recorded that way in national accounts, the difference between bequeathable (fungible) wealth and retirement wealth rests on the basic motives for saving. Hence, in theoretical models or in simulation exercises one is usually concerned with describing changes in total capital accumulation (i.e. total private wealth even if annuitized), but in the empirical work the extent of substitutability is usually assessed by comparing bequeathable wealth on the one hand and retirement wealth (or just public retirement wealth) on the other.

Section 2 has addressed the question, how much private saving needs to be substituted for PAYG-financed retirement income provision in order to stabilize the current PAYG system contribution rates (this is the second substitution mechanism). In this section, we review what we know about possible crowding-out effects vis-à-vis other savings (the first substitution mechanism). Buying smaller homes, the example that we mentioned in the outset of this section, is the most probable avenue for the first of the two substitution mechanisms.

Crowding out is an important policy issue for two reasons. First, a central argument put forward in pension reform discussions is the macroeconomic superiority of a funded system vis-àvis a PAYG system. ${ }^{7}$ This argument is valid only to the extent that new savings is created which adds to the capital stock and therefore promotes economic growth. This requirement holds a fortior $i$ when the transition costs of a pension reform are considered. Second, if prefunding is incensed by tax relief, full crowding out implies that these subsidies are merely windfall gains that shift existing savings from one form to another. We discuss the first point here and the second in the following subsection.

The extent of crowding out is subject of the famous debate between Feldstein (1974) and Barro (1974). Our reading of the controversy is that we do not have reliable estimates of the quantitative extent, but that the evidence supports a positive effect on total savings when the

\footnotetext{
${ }^{6}$ Bernheim (1987a and b) first addressed this issue.

7 Macroeconomic superiority refers to a de novo system. Welfare superiority including transition costs requires additional effects over and above this capital accumulation, strengthening the necessity of new saving. See Börsch-Supan (1999), Breyer (2000) and Sinn (2000) for an exchange on this point.
} 
PAYG system is reduced, e.g., in a partial transition as described in the previous subsection. We do not have reliable econometric estimates because crowding out takes place by the behavioral adaptation of generations, thus needs long periods of time, in which many other macroeconomic circumstances change.

Auerbach and Kotlikoff (1983) pioneered the discussion on the difficulties with the identification of the substitution parameters both in time series and cross sectional studies for the US. The structural instability of the parameters is due to the changes in population structure and to the fluctuations in interest rates as well as in contribution rates during the transition after the introduction of a new pension system.

For Europe the empirical evidence is scanty and there exists a wide variety of results, making it particularly hard to reach any conclusion. To our knowledge time series studies include Rossi and Visco $(1994){ }^{8}$ for Italy, who are able to attribute part of the decline occurred during the 1980s in the saving rate to the increased generosity of the social security in the 1970s. In other countries the relationship between pension wealth and private fungible wealth emerging from time series data is poorly determined ${ }^{9}$. Cross sectional analysis based on Italian micro data (Brugiavini, 1987; Jappelli, 1995) obtain low estimates of the substitution parameter. Recent studies for the Netherlands obtain mixed results. In particular, by using the Dutch Socio Economic Panel (SEP) data on private wealth and on (constructed) data on social security wealth and pension wealth, Alessie, Kapteyn and Klijn (1997) and Kapteyn, Alessie and Lusardi (1999) have investigated the question whether or not there exists displacement between discretionary private wealth on the one hand and social security and pension wealth on the other hand. For pension wealth they do not find any evidence of displacement, while for social security wealth they find full displacement ${ }^{10}$.

Clear cut "experiments" in which the pension system changes but everything else remains constant, are hard to come by. Attanasio and Brugiavini (1997) rely directly on a test of how changes in saving rates are related to changes in pension wealth following the 1992 Reform of the Italian Social Security System in a "quasi-natural-experiment" setting. They find that

\footnotetext{
${ }^{8}$ The studies are based on long run relationships between, saving, growth and changes in public pension wealth.

9 See Kohl and O'Brien (1998) for a detailed survey.

${ }^{10}$ See also Euwals (2000). The evidence based on cross sectional data for the USA (Hubbard, 1986) and for Canada (King and Dicks-Mireaux, 1982), is also rather mixed.
} 
households whose public pension wealth was substantially curtailed by the reform show a marked increase in their private saving rate.

Given this lack of conclusive econometric evidence, one can infer the extent of crowding out from an overlapping generations (OLG) model. Börsch-Supan, Heiss and Winter (2001) calibrate such a model to German data and conclude that substitution amounts to about one third, leaving two thirds new saving. This estimate is fairly robust for a reasonable variation in the underlying parameters, so it is probably a good guess for other countries as well. However, it is based on the tight structure of an OLG model and thus only a last resort in search for a badly needed number.

How could we get better information? The crowding-out issue is a prime example of the virtues of observing policy variation in cross-national data. Only different mixtures of public and private pension systems can identify how people react with their saving behavior to those different mixed. Europe is a great laboratory in this respect, and particularly these days with many different approaches to pension reform under way. We need to collect data during the initial phases in order to predict the future better. Currently, we are not only not really able to anticipate problems, we also miss a golden opportunity to exploit the "European Laboratory".

\section{Will Workers Save Voluntarily?}

Closely related to the question of substitution is the question whether workers will save voluntarily for self-financed old-age insurance - or whether it is necessary to make self-financed old-age insurance mandatory. This is a hotly debated issue in the policy arena, particularly in the current pension reform processes in Germany and Italy. The argument pro mandatory savings is mainly the need to cover all persons in order to avoid pockets of poverty and to prevent moral hazard. The arguments against mandatory savings essentially rest on the well known economic efficiency arguments against taxation. One advantage of private savings for old age as opposed to PAYG contributions is that the latter have mainly tax character (Börsch-Supan and Reil-Held, 2000), therefore create dead weight losses, while private saving does not. Making saving mandatory, however, introduces an element of force, thus shifts savings understood as voluntary insurance premia towards mandatory taxes.

The issue is complicated by moral hazard. As long as the government provides pension income of last resort, voluntary savings is a waste - from the individual point of view, at least among 
those in the lowest parts of the earnings distribution - if one can just as well apply for social assistance. People may therefore opt for mandatory savings in order to reduce moral hazard. How do you find out? Asking workers directly provides unreliable and potentially strategic answers. There are also strong framing effects. It does not surprise if workers are reported to favor self-provided old-age insurance when surveys are conducted by pension funds and insurance agencies, while they prefer state-provided old-age insurance when asked by the unions. Besides framing, respondents usually have no realistic alternatives between to choose - with all their costs and benefits clearly stated. Pure intentional questions tend to give misleading answers.

Boeri, Börsch-Supan and Tabellini (2001) used a different approach and posed asked if workers would like to partially opt out of the public pension system. They formulated this question so as to mean that they and their employer would only pay half the contributions in the future, but they would also receive only half of the pension rights once they opt out. Past contribution would be valued at their old benefit levels. This question clearly states costs and benefits, although workers may just not know not the contributions and benefits of their pension system. The questions were posed to a large sample of French, German, Italian and Spanish workers. In order to shed light on the issue at hand - voluntary or mandatory? - the opting-out proposal was presented in several versions. In the first version, the amount saved by the reduced contributions was simply added to net income. In this case, the employee had the free choice of how to dispose of this money. In a follow up question, the employee was constrained to invest the amount rebated in an old-age fund of his own choice, either private or employer-based. A third version, asked to those who agreed to the first opting-out proposal, imposed a transition burden in the form of a lower valuation of future pension rights.

In all four countries only a small fraction does not know or refuses to answer, but nowhere was an absolute majority willing to opt out. In Germany and Italy, about $47 \%$ of those who give a valid answer would like to opt out of the public pension systems, while some $48 \%$ would prefer to remain in it. In France and in Spain, the approval of an opting-out deal is much lower, about $24 \%$ and $19 \%$. The rate of acceptance decreases with age and rises with income and education. Males are more likely to accept. More informed individuals (about pension system features) also are more likely to accept the proposal. 
Workers who wanted to opt out were also asked what they do with the money. Interestingly, most workers would indeed use the money for self-provided old-age insurance. One might be tempted to conclude that there is some, although not overwhelming empirical support for voluntary self-insurance.

It is more complicated, though. The second version of the opting-out proposal constrains individuals to invest the rebated contributions. One might expect that this would reduce the willingness to opt out relative to the previous question. But one finds the opposite: If the money saved has to be invested into a private old-age provision of one's own choice, the acceptance rate of the proposal rises from $47 \%$ to $67-71 \%$ in Italy and Germany, from $19 \%$ to $63 \%$ in Spain, and from $24 \%$ to $50 \%$ in France. A mandatory private pillar has more supporters than a voluntary supplemental provision, although most respondents who would accept the unconditional opting out proposal, would anyway invest in old-age provision.

To make matters even more complicated, shifting the financial burden of old-age insurance from state to self-financing incurs a transition burden. Opting out of the PAYG system is only feasible if someone bears additional contributions: those who have already retired need to be financed through the existing PAYG system, while at the same time future retirees have to save for themselves. This transition burden can be financed either by cutting existing pension benefits thereby lowering the PAYG contributions of current workers and making room for savings, or by adding savings to the current contributions. Both options are unattractive and are likely to reduce the political support for of a fully funded system.

With a third version of the opting-out proposal, Boeri et al. (2001) intended to find out to what extent individuals are willing to pay for the transition burden in order to get out of the pay as you go system. All those who had accepted the (unconditional) opting out proposal were asked whether they would still accept a less favorable proposal, offering the same tax rebate but a smaller future pension. Not surprisingly, the acceptance rate is considerably lower than without a burden. But the extent to which opting out is rejected may surprise and suggests that perhaps the question was not well understood. In Germany and Italy, only a quarter of those who had accepted the previous proposal are still willing to opt out. In France and Spain, where fewer people accepted the unconditional opting out proposal, the decline is less pronounced: $40-50 \%$ still want to opt out even under a transition burden. Altogether, these numbers convey a similar negative result: in all four countries only little more than $10 \%$ of the 
respondents is willing to opt out if that entails bearing the transition burden envisaged in our question.

The exercise by Boeri et al. (2001) was a first and promising step and conveys an important methodological insight: they needed new data to get new insights. More experimentation with such complicated questions, however, is needed. In particular, we need data collection that mixes the experience and insights of economists and social scientists in this important area.

\section{What Kind of Incentives May Induce Saving?}

Section 7 suggests that workers, at least in France, Germany, Italy and Spain, prefer mandatory saving for self-financed old-age insurance, and given the necessity of a transition burden, a voluntary transition may not work at all. Most economists, however, do not like such mandatory saving plans because they resemble mandatory contributions to pay-as-you-go pension systems. These latter contributions are well-known to have the character of taxes and thus discourage labor supply. Isn't it possible to have it both ways: Encourage savings by tax incentives such that everybody does voluntarily what is required? There are also technical reasons to study the effects of tax incentives on savings: In most pension system transition that have occurred in recent history, the governments wanted to speed up the transition by tax relieves for private old-age provision.

Economic theory is ambiguous on the effect of tax subsidies on the volume of private savings because the substitution effect (higher after tax returns make saving more attractive than consumption) has an impact opposing that of the income effect (the subsidy increases total income which increases consumption in all periods). Moreover, the interpretation of the available evidence is hotly debated, see especially the controversy between Venti and Wise (1990) on one side, and Gale and Scholz (1994) and Attanasio and De Leire (1994) on the other side, referring to the effects of tax subsidies on American households' retirement saving and discussing the "creation" of new saving. The issues are summarised by Skinner and Hubbard (1996) for the US and by Attanasio and Banks (1998) for a comparison of the US and the UK.

In Continental Europe, this debate is complicated by the fact that in some cases households seem to be "overannuitized". Evidence by Börsch-Supan and Stahl (1991) and Börsch-Supan $(1992,1994)$ shows that the annuity income of a majority of pensioners (mostly PAYG income provided through the public system) by far exceeds consumption expenditures. The next gen- 
eration of pensioners appears to be aware of this fact, since saving rates in Germany drop for the now middle aged cohorts. Given this trend, a reduction in public pension wealth may not necessarily be channeled into new savings, or only after a transition period of new costly learning. At the same time, these households, if left to their own devices, may also shun pension assets because they do not want to lock their wealth into long term saving for retirement. This debate teaches two lessons. First, we do not really know whether saving-related tax relief or similar subsidies increase total saving. Second, we do know that subsidies strongly increase saving in the specific form that is subsidized, possibly to the detriment of other saving forms, see Section 6.

Obviously, we again have a case for cross-national data collection. We need policy variation and we got policy variation across the European countries. The sheer variety of tax treatment of private pensions across Europe generates the "European Laboratory" that helps us to detect which type of taxes encourage or discourage different types of assets. ${ }^{11}$

\section{Conclusions}

We have surveyed the ongoing debate on the role of self-financed versus state-financed old-age insurance. From simulation studies calibrated on German data we have learned that freezing current PAYG contributions requires a funded component of about one third of the existing benefits. This corresponds to an increase in the saving rate between $1.8 \%$ and $3.2 \%$ of the current rate. It is much harder to judge how much of this is "new saving" or whether it simply crowds out other forms of capital accumulation. In fact, the econometric evidence does not allow us to draw firm conclusions on the degree of substitutability between public pension "mandatory saving" and private saving. The picture is further blurred by tax incentives provided in some countries to some forms of capital accumulation, hence making it even harder to reach a conclusion on whether tax incentives on pension assets will encourage this form of saving and contribute to the creation of new saving.

Hence, while we find that in studying saving behavior and the effects of public policy on it, theoretical models and simulation studies deliver useful information and qualitative policy pre-

\footnotetext{
11 See Dilnot (1992), World Bank (1999) and Börsch-Supan and Lührmann (2000) on the variety of pension taxation rules in Europe and elsewhere.
} 
scriptions, we cannot provide reliable information that helps governments reliably anticipate problems. The lack of good quality longitudinal data of European households strongly impedes empirical research that could deliver quantitative results and permit judgements on the dominance of opposing effects.

Longitudinal data is essential here because saving takes place over the life-cycle. Cross sectional data - i.e., data in just one point of time - are obviously unable to identify life-cycle behavior. Only longitudinal data can enable researchers to draw conclusions on the effects of pension reforms and welfare reforms on saving, on the interaction of credit markets arrangements and liquidity constraints, and on the role of precautionary and bequest motives alongside the traditional life cycle motives in explaining choices.

Equally essential is cross-national data, collected under strict comparability. Only crossnational data provides the necessary policy variation - only different mixtures of public and private pension systems can identify how people react with their saving behavior to those different mixed. Europe is a great laboratory in this respect, and particularly these days with many different approaches to pension reform under way. We need to collect data during the initial phases in order to predict the future better. Currently, we are not only ill-positioned to anticipate problems, we may also miss a golden opportunity to exploit the "European Laboratory". 


\section{References}

Alessie, R., and A. Kapteyn (2001): Household Savings in the Netherlands, Research in Economics, forthcoming.

Alessie, R., A. Kapteyn and F. Klijn (1997), Mandatory pensions and personal savings in the Netherlands, De Economist, 145, no. 3, pp. 291-324.

Attanasio , O. and T. De Leire (1994), IRAS and household saving revisited: some new evidence, NBER working paper 4900.

Attanasio O. and A. Brugiavini, (1997), L'effetto della Riforma Amato sul risparmio delle famiglie italiane, Ricerche Quantitative per la Politica Economica-1995, Banca d'Italia-CIDE (eds.), Roma

Attanasio O., and J. Banks (1998), Trends in household saving don't justify tax incentives to boost saving, Economic Policy, October.

Auerbach, A.J. and L.J. Kotlikoff (1987), Dynamic Fiscal Analysis, Cambridge University Press, Cambridge, England.

Auerbach, A.J., L.J. Kotlikoff, Hagemann, R.G., and G. Nicoletti (1989), The Economic Dynamics of an Ageing Population: The Case of Four OECD Countries, OECD Economic Studies No. 12.

Banks, J., R. Blundell and S. Tanner (1998), Is There a Retirement-Savings Puzzle? American Economic Review 88(4), pages 769-88.

Barro R. J. (1974), Are Government Bonds Net Wealth?, Journal of Political Economy, $82,5,1095-117$

Bernheim B.D. (1987a), The Economic Effects of Social Security: Toward a Reconciliation of Theory and Measurement, Journal of Public Economics, 33, 273-304

Bernheim B.D. (1987b), Dissaving After Retirement: Testing the Pure Life Cycle Hypothesis, in Z. Bodie, J.Shoven and D.Wise, eds. Issue in Pension Economics, NBER, The University of Chicago Press, Chicago.

Birg, H., and A. Börsch-Supan (1999), Für eine neue Aufgabenteilung zwischen gesetzlicher und privater Altersversorgung, GDV: Berlin.

Boeri, T., A. Börsch-Supan und G. Tabellini (2001), Would you Like to Shrink the Welfare State? The Opinions of European Citizens. Economic Policy, 32, in press.

Börsch-Supan, A. (1992): Saving and consumption patterns of the elderly: the German case. Journal of Population Economics, 5, 289-303.

Börsch-Supan, A. (1994): Savings in Germany - Part II: Behavior. In: Poterba, J. (ed.), International Comparisons of Household Savings. Chicago, London: University of Chicago Press, 207-236.

Börsch-Supan, A. (1996), The Impact of Population Ageing on Savings, Investment and Growth in the OECD Area. In: OECD, Future Global Capital Shortages: Real Threat or Pure Fiction? Paris: OECD, 103-141.

Börsch-Supan, A. (1999), Zur deutschen Diskussion eines Übergangs vom Umlage- zum Kapitaldeckungsverfahren in der Gesetzlichen Rentenversicherung. Finanzarchiv, Band 55, Heft 3, S. 400-428. 
Börsch-Supan, A. (2000), A Model under Siege: A Case Study of the Germany Retirement Insurance System, The Economic Journal, Vol. 110 No. 461, F24-45.

Börsch-Supan, A., ed. (2001a), International Comparisons of Household Saving: A Study of Life-Cycle Savings in Seven Countries, New York: Academic Press.

Börsch-Supan, A. (2001b), The German Savings Puzzle, Research in Economics, 55, in press.

Börsch-Supan, A. und M. Lührmann (2000), Prinzipien der Renten- und Pensionsbesteuerung, Frankfurter Institut: Bad Homburg.

Börsch-Supan, A., and K. Stahl (1991): Life-cycle savings and consumption constraints. Journal of Population Economics, 4, 233-255.

Börsch-Supan, A. und A. Reil-Held, 2001, How much is Transfer and how much Insurance in a Pay-As-You-Go System? The German Case, Scandinavian Journal of Economics, in press.

Börsch-Supan, A. and J. K. Winter (2001), Population Aging, Savings Behavior and Capital Markets. Sonderforschungsbereich 504, Universität Mannheim.

Börsch-Supan, A., F. Heiss und J. K. Winter (2001), Pension Reform, Capital Markets, and the Rate of Return, mimeo, University of Mannheim and Herbert-Giersch-Stiftung, Magdeburg.

Börsch-Supan, A., A. Reil-Held, R. Rodepeter, R. Schnabel and J. Winter (2001): The Geramn Saving Puzzle, Research in Economics, forthcoming.

Breyer, F. (2000), Kapitaldeckungs- versus Umlageverfahren, Perspektiven der Wirtschaftspolitik.

Brugiavini, A. (1987), Empirical Evidence on Wealth Accumulation and the Effects of Pension Wealth: an Application to Italian Cross Section Data", 1987, Financial Markets Group, D.P. 20, LSE, London.

Brugiavini, A., and M. Padula (2001), Too much for Retirement? Saving in Italy, Research in Economics, forthcoming.

Brugiavini, A., and G. Weber (2001): Household Savings: Concepts and Measurement. In: Börsch-Supan, A. (ed.), International Comparisons of Household Saving, New York: Academic Press.

Dilnot, A.W. (1992): Taxation of Private Pensions: Costs and Consequences. In: OECD, Private Pensions and Public Policy, Paris: OECD.

European Commission (2000), The Contribution of Public Finances to Growth and Employment: Improving Quality and Sustainability, Communication from the European Commission to the Council and the European Parliament.

Euwals, R. (2000) 'Do Mandatory Pensions Decrease Household Savings: Evidence for the Netherlands.' De Economist, Vol. 148, pp 643-670.

Feldstein, M. (1974), Social Security, Induced Retirement and Aggregate capital accumulation, Journal of Political Economy, 82,5, 905-926

Gale W.J. and J.K. Scholz (1994) IRAs and household saving, American Economic Review, $84,1233-1260$ 
Gruber, J., and D. Wise, eds., (1999), Social Security and Retirement Around the World, The University of Chicago Press: Chicago.

Heller, P., 1989, Aging, Savings and the Sustainability of the Fiscal Burden in the G7countries: 1980-2025. IMF.

Hubbard R.G., (1986) Pension wealth and individual saving, some new evidence, Journal of Money Credit and Banking, 18, 167-178

Jappelli T. (1995), Does social security wealth reduce the accumulation of private wealth? Evidence from Italian survey data, Ricerche Economiche, 49,1-31

Jappelli, T., and F. Modigliani (1998), The Age-Saving Profile and the Life-Cycle Hypothesis, CSEF Working Paper No. 4, University of Salerno.

Kapteyn, A., R. Alessie and A. Lusardi (1999), "Explaining the wealth holdings of different cohorts: productivity growth and social security", mimeo, Tinbergen Institute.

King M. and L. Dicks-Mireaux, (1982), Asset Holding and the Life Cycle, Economic Journal, 92

Kohl, R. and P. O'Brien (1998), The Macroeconomics of Ageing, Pensions and Savings: A Survey, OECD Working Paper AWP1.1, Paris.

Modigliani, F. and R. Brumberg (1954), Utility Analysis and the Consumption Function: An Interpretation of Cross-section Data. In: Kurihara, K. (ed.), Post-Keynesian Economics. New Brunswick, NJ: Rutgers University Press.

National Academy of Sciences (NAS, 2001), A Research Agenda and New Data for An Aging World, forthcoming.

Rossi N. and I. Visco (1994): Private Saving and the Government deficit in Italy, In: Ando A., L. Guiso and I.Visco. (eds.), Saving and the Accumulation of Wealth, Cambridge: Cambridge University Press.

Sinn, H.W. (2000), Why to Fund and Why Not to Fund, mimeo, CES, Munich

Skinner, J. und R.G. Hubbard (1996), Assessing the Effectiveness of Saving Incentives, Journal of Economic Perspectives 10(4), 73-90.

Venti S. and D. Wise (1990), Have IRAs increased U.S. Savings? Evidence from consumer expenditure surveys, Quarterly Journal of Economics, 105, 661-98.

World Bank (1999): The Tax Treatment of Funded Pensions, World Bank Pension Reform Primer 2.3, Washington, D.C. 


\section{Discussion Paper Series}

Mannheim Research Institute for the Economics of Aging Universität Mannheim

To order copies, please direct your request to the author of the title in question.

\begin{tabular}{|c|c|c|c|}
\hline Nr. & Autoren & Titel & Jahr \\
\hline 01-02 & Axel Börsch-Supan & $\begin{array}{l}\text { Eine Blaupause für eine nachhaltige } \\
\text { Rentenreform in Deutschland }\end{array}$ & 02 \\
\hline $02-02$ & Axel Börsch-Supan & A Blue Print For Germany's Pension Reform & 02 \\
\hline 03-02 & Axel Börsch-Supan & $\begin{array}{l}\text { Reduction of Working Time: Does it Decrease } \\
\text { Unemployment? }\end{array}$ & 02 \\
\hline 04-02 & Axel Börsch-Supan & $\begin{array}{l}\text { Übergang statt Untergang: Wider die Furcht vor } \\
\text { dem Untergang der Arbeit }\end{array}$ & 02 \\
\hline 05-02 & $\begin{array}{l}\text { Daniel Houser, } \\
\text { Joachim Winter }\end{array}$ & $\begin{array}{l}\text { How Do Behavioral Assumptions Affect Structural } \\
\text { Inference? Evidence Form A Laboratory } \\
\text { Experiment }\end{array}$ & 02 \\
\hline 06-02 & Axel Börsch-Supan & $\begin{array}{l}\text { International Comparison of Household Savings } \\
\text { Behaviour: The German Savings Puzzle }\end{array}$ & 02 \\
\hline 07-02 & \begin{tabular}{|l|} 
Tito Boeri, \\
Axel Börsch-Supan, \\
Guido Tabellini \\
\end{tabular} & $\begin{array}{l}\text { Would you Like to Reform the Pension System? } \\
\text { The Opinions of European Citizens }\end{array}$ & 02 \\
\hline $08-02$ & $\begin{array}{l}\text { Axel Börsch-Supan, } \\
\text { Florian Heiss, } \\
\text { Miki Seko } \\
\end{array}$ & $\begin{array}{l}\text { Housing Demand in Germany and Japan } \\
\text { Paper in memoriam of Stephen King }\end{array}$ & 02 \\
\hline $09-02$ & $\begin{array}{l}\text { Moshe Ben-Akiva, } \\
\text { Daniel McFadden, } \\
\text { Kenneth Train, } \\
\text { Axel Börsch-Supan, } \\
\text { et.al. }\end{array}$ & Hybrid Choice Models: Progress and Challenges & 02 \\
\hline $10-02$ & \begin{tabular}{|l} 
Axel Börsch-Supan, \\
Alexander Ludwig, \\
Joachim Winter \\
\end{tabular} & Aging and International Capital Flows & 02 \\
\hline $11-02$ & Axel Börsch-Supan & Labor market effects of population aging & 02 \\
\hline $12-02$ & Axel Börsch-Supan & $\begin{array}{l}\text { Kann die Finanz- und Sozialpolitik die } \\
\text { Auswirkungen der Bevölkerungsalterung auf den } \\
\text { Arbeitsmarkt lindern? }\end{array}$ & 02 \\
\hline 13-02 & $\begin{array}{l}\text { Florian Heiß, } \\
\text { Jens Köke }\end{array}$ & $\begin{array}{l}\text { Dynamics in ownership and firm survival: } \\
\text { Evidence from corporate Germany }\end{array}$ & 02 \\
\hline $14-02$ & Axel Börsch-Supan & $\begin{array}{l}\text { "Global Aging" an der Jahrtausendwende: } \\
\text { Die demographischen Herausforderungen des } \\
\text { 21. Jahrhunderts }\end{array}$ & 02 \\
\hline $15-02$ & Axel Börsch-Supan & $\begin{array}{l}\text { Nach der Reform ist vor der Reform: Weitere } \\
\text { Schritte für eine nachhaltige Reform der } \\
\text { Altersvorsorge in Deutschland }\end{array}$ & 02 \\
\hline $16-02$ & Florian Heiss & Specification(s) of Nested Logit Models & 02 \\
\hline
\end{tabular}




\begin{tabular}{|l|l|l|c|}
\hline $17-02$ & Axel Börsch-Supan & $\begin{array}{l}\text { What We Know and What We Do NOT Know } \\
\text { About the Willingness to Provide Self-Financed } \\
\text { Old-Age Insurance }\end{array}$ & 02 \\
\hline $18-02$ & $\begin{array}{l}\text { Axel Börsch-Supan, } \\
\text { Agar Brugiavini }\end{array}$ & Savings: The Policy Debate in Europe & 02 \\
\hline
\end{tabular}

